Недељко В. Радосављевић

Историјски институт

Београд

nedjo.radosavljevic@gmail.com
Оригинални научни рад

примљено: 14. јун 2011

прихваћено: 1. октобар 2011

\title{
ДАБРОБОСАНСКА (САРАЈЕВСКА) МИТРОПОЛИЈА У РАТНОМ ПЕРИОДУ СРПСКЕ РЕВОЛУЦИЈЕ (1804-1815)*
}

Сажетак: У раду су дати основни подаци о положају Дабробосанске (Сарајевске) митрополије о оквиру Васељенске патријаршије за време ратног периода Српске револуције 1804-1815. Наглашено је да се ради о тада највећој епархији бивше Пећке патријаршије, са економски најмоћнијом Српском општином у Сарајеву. Извршено је поређење ситуације у којој се налазила Православна црква у Босанском пашалуку са стањем у Београдском пашалуку уочи избијања Првог српског устанка. Такође су анализирани улога и деловање тадашњег дабробосанског митрополита Калиника, али и његових викарних епископа, који су га замењивали у време док је био члан Светог синода Васељенске патријаршије.

Кључне речи: Васељенска патријаршија, Османско царство, Сарајево, митрополија, Српска револуција, црква, митрополити, верници.

У време уочи избијања Првог српског устанка, Дабробосанска (Сарајевска) митрополија била је у границама које су одређене након великих геополитичких промена на Балканском полуострву проузрокованих Хабзбуршко-османским ратом 1737-1739, и одредбама Београдског мира којим је он окончан. ${ }^{1}$ У Босанском

\footnotetext{
* Рад је настао као резултат истраживања на пројекту Министарства просвете и науке Републике Србије Европа и Срби (1804-1918): подстицаји и искушења европске Модерне (Ев. Бр. 177031), који се реализује у Историјском институту у Београду под руководством др Славенка Терзића, научног саветника. Аутор чланка др Недељко В. Радосављевић, виши научни сарадник, Историјски институт, Београд. Е-пошта nedjo.radosavljevic@gmail.com.

${ }^{1}$ Историјом Православне цркве у Босни и Херцеговини бавило се више аутора. Од дела која заслужују посебну пажњу треба поменути књиге Бранислава Ђурђева, Божа Маџара и Бориса Нилевића: Branislav Đurđev, Uloga crkve u starijoj istoriji srpskog naroda, Sarajevo 1964; Božo Madžar, Pokret Srba u Bosni $i$ Hercegovini za vjersko-prosvjetnu samoupravu, Sarajevo 1982; Борис Нилевић, Српска православна ирква у Босни и Херцеговини до обнове Пећке патријаршије, Сарајево 1998. Посебан осврт на стање цркве у Босни и Херцеговини крајем 18. и почетком 19. века дао је и Ђоко Слијепчевић у делу Историја Српске православне иркве II, Београд 1991. На објављивању извора за историју цркве на тим просторима озбиљно се радило још почетком 20. века. Тако су изузетно важну, прворазредну грађу, у Гласнику
} 
пашалуку тада су постојале четири епархије ${ }^{2}$, а Дабробосанска је била највећа међу њима. $^{3}$ У оквиру својих граница она је, уз мање корекције, опстала до краја османске власти у Босни и у Херцеговини. Никакве промене њених граница, па ни смена архијереја који јој је био на челу, нису се десили ни у време укидања аутокефалности Пећке патријаршије 21. септембра 1766.

Дабробосанска митрополија је по броју православних кућа до 1808. била и највећа од свих епархија укинуте Пећке патријаршије. Сразмерно томе, плаћала је највиши годишњи порез султановој благајни. Уочи Првог српског устанка 1804 , број православних кућа у њој сигурно је био већи од 15.000, колико их је било у Београдској митрополији, док их је у Ужичко-ваљевској митрополији било 12.597. То се може закључити из чињенице да је порез на њу износио 15.500 акчи. У исто време, Београдска је плаћала 15.000, а Ужичко-ваљевска митрополија 12.500 акчи. ${ }^{4}$

Од 1766, када је укинута аутокефалност Пећке патријаршије, до 1802, на челу Дабробосанске митрополије променило се више митрополита. С обзиром на њену величину и број верника, ова епархија била је једна од ретких која је, готово по правилу, имала и викарног епископа. Он је носио титулу митрополит кратовски. На челу епархије је од 1766. до 1776. био митрополит Серафим, добро образован архијереј бугарског порекла, који је претходно био игуман Рилског манастира и,

Земалског музеја објавили Сејфудин еф. Кемура и Владимир Ћоровић, Прилози за хисторију Православне иркве у Босни и Херцеговини у XVIII и XIX стољећу, Гласник Земаљског музеја у Босни и Херцеговини (ГЗМ) XXIV, Сарајево 1912, 413-441. Већи број записа и натписа објавио је и Љубомир Стојановић у шестотомном делу Стари српски записи и натписи I-VI, Београд - Сремски Карловци 1902-1926. Ипак, поред бројних радова и објављених извора, изостала је синтеза о Православној цркви у Босанском пашалуку и њеним појединим епархијама у време управе Васељенске патријаршије, посебно у времену од 1766. до почетка танзиматских реформи 1839.

2 Поред Дабробосанске, на подручју Босанског пашалука постојале су и Херцеговачка, Зворничка и Рашка митрополија. Висок митрополијски ранг ових епархија није, међутим, био резултат никакве црквене аутономије нити њихове сложене унутрашње структуре, већ прихватања обичаја Васељенске патријаршије да готово сви архијереји носе митрополитско звање, а све епархије ранг митрополија. Недељко Радосављевић, Православна ирква у Београдском пашалуку 1766-1831, управа Васељенске nатријариије, Београд 2007, 439.

${ }^{3}$ По ферману којим се за дабробосанског митрополита 1776. потврђује митрополит Кирил, територија те епархије обухватала је простор Високог, Травника, Јајца, Ускопља, Језера (Ђол Хисар), Ливна, Гламоча, Вакуфа, Козарца, Бање Луке, Дервенте, Тешња, Маглаја, Сребренице, Вишеграда... С. Кемура - В. Ћоровић, нав. дело, док. 3, 416. Територија Дабробосанске митрополије обухватала је највећи део Босанског пашалука, односно његовог Сарајевског санџака. На северу и западу била је ограничена државном границом, на југу Херцеговачком митрополијом, а на истоку и југоистоку Зворничком митрополијом, затим Ужичко- ваљевском митрополијом која је била у саставу Београдског пашалука, и Рашком митрополијом. Рашка, касније Рашко-призренска митрополија, такође је била у склопу Сарајевског санџака, изузев у периоду од 1790. до 1817, када је био установљен Новопазарски санџак.

Када је реч о имену митрополије, у администрацији Васељенске патријаршије коришћена су оба назива, и Сарајевска и Дабробосанска, често и Босанска, док су се њени архијереји потписивали различито, као дабробосански, сарајевски, боснасарајевски, босански и сарајевски и слично. О томе видети опширније Н. Радосављевић, Грађа за историју Сарајевске (Дабробосанске) митрополије, Београд 2007, passim. У овом раду за митрополију је као основно узето старије име, које је такође често коришћено, посебно међу нижим свештенством.

${ }^{4}$ Само је обједињена Рашко-призренска и скендеријска митрополија после 1808. плаћала већи пешкеш, који је износио 16.000 акчи. Иван С. Јастребов, Податщи за историју Српске иркве, Београд 1879, 33. 
кратко, штипски (ћустендилски) митрополит. Увидевши расуло које је владало у Пећкој патријаршији, а као заговорник не само канонског већ и управног јединства целокупног православља, он је потписао молбу за њено укидање. Међутим, у епархији је имао јако добре односе са верницима и нижим свештенством. Склон мирном монашком животу, по сопственој жељи која је у Васељенској патријаршији готово увек поштована, повукао се у Рилски манастир, где је живео до смрти 1800. године. ${ }^{5}$ Уместо њега, дошао је митрополит Кирил, први кога је поставила Васељенска патријаршија. Султан је ферманом од 4. маја 1776. потврдио његов избор. ${ }^{6}$ По мишљењу Владислава Скарића и Саве Вуковића, он је највероватније био један од Серафимових придворних монаха. ${ }^{7}$ На челу Дабробосанске митрополије Кирил је био само четири године. За то време, био је суочен са различитим судским споровима, јер је епархија одраније била оптерећена дуговима старим и до 30 година, али је највећи део тих проблема успео да реши. ${ }^{8}$

Марта 1779. Кирила је позвао васељенски патријарх Софроније да из епархије дође у Цариград. Пре одласка, управу над епархијом предао је намесницима Јеротеју и Пахомију, који су имали обавезу да уредно сакупљају архијерејске приходе и шаљу уобичајену милостињу у Цариград. У истом документу се, између осталог, помиње и дуг који митрополија има према Патријаршији, и који очигледно није био мали. ${ }^{9}$ Разлог одласка митрополита Кирила на основу пристигле патријаршијске грамате није могуће утврдити, али с обзиром на то да се не помињу никакве казне нити премештаји, већ само ирквени послови, може се претпоставити да се радило о унапређењу, премештају у другу епархију или о одлуци да се повуче у неки од манастира. То посредно потврђује и берат новог дабробосанског митрополита Пајсија. У том берату, издатом 28. марта 1780, наводи се да му митрополит Кирил добровољно уступа епархију. Поред општих места за ову врсту исправе, други подаци о новом митрополиту сем да је вредан, да добро познаје народне обичаје, и да је изабран од патријарха и сабора архијереја нису наведени. ${ }^{10}$ Пајсије је деловао у сложеном времену, у коме је морао да, у интересу верника и цркве у целини, буде у добрим односима са локалним властима. Сарајевска црквена општина у почетку се жалила на њега јер још увек није потврдио њен статут, и тражио је више новца него што му по њему припада, али је тај неспоразум убрзо отклоњен. ${ }^{11}$ Након што је на молбу грађана успео да издејствује ферман којим се дозвољава обнова сарајевске цркве која је изгорела у

\footnotetext{
${ }^{5}$ Н. Радосављевић, Шест портрета православних митрополита 1766-1891, Београд 2009, $15-25$.

${ }^{6}$ С. Кемура - В. Ћоровић, нав. дело, док. 3, 416.

${ }^{7}$ Вероватно се радило о митрополијском протосинђелу, али се не може одбацити ни могућност да је Кирил био викарни епископ. За ферман о потврђивању, митрополит Кирил је царској хазни уплатио пешкеш од 6.000, 00 аспри, Владислав Скарић, Српски православни народ и црква у Сарајеву у 17. и 18. вијеку, Изабрана дјела II, Сарајево 1985, 45; Сава еп. Вуковић, Српски јерарси од деветог до даведесетог века, Београд - Подгорица - Крагујевац 1995, 277.

${ }^{8}$ В. Скарић, нав. дело, 45.

${ }^{9}$ Исто, 46.

${ }^{10}$ С. Кемура - В. Ћоровић, нав. дело, док 7, 422.

${ }^{11}$ На ову жалбу из Цариграда је као одговор стигао ферман у коме се тачно наводи које дажбине и у ком износу митрополит може захтевати, В. Скарић, нав. дело, 46.
} 
пожару 1. јула 1788, њихови односи постали су много бољи. ${ }^{12}$ Молба грађана Сарајева митрополиту Пајсију написана је 6 (17) јануара 1793. Радови су убрзо отпочели и завршени су децембра те године, а у знак захвалности одлучено је да се име митрополита Пајсија увек помиње у литургији која се служи у сарајевској цркви. ${ }^{13}$ У време последњег хабзбуршко-османског рата 1788-1791, Пајсије није подржао устанак и оснивање босанских фрајкора, већ је остао лојалан османским властима и трудио се да заштити вернике. ${ }^{14}$ На челу митрополије остао је до смрти 1802. године. У сиџилу Цареве џамије у Сарајеву сачуван је препис берата од 13. новембра 1802, у коме се наводи да је митрополит умро, и да је народ замолио да се именује његов наследник. Свети синод Васељенске патријаршије је уместо њега изабрао и предложио султану митрополита Калиника І. Султан је тај избор потврдио и новом митрополиту издао уобичајени берат. ${ }^{15}$ Време управе митрополита Калиника I највећим делом се подударало са ратним периодом Српске револуције, што је положај хришћанског становништва у Босанском пашалуку учинило знатно сложенијим него до тада.

Збивања у Београдском пашалуку, у коме је дошло до убиства законитог везира и преузимања власти од одметнутих јаничара, подржаних од Османа Пазваноглуа из Видинског санџака, била су све време уско повезана са догађајима у Босанском пашалуку, где је централна власт имала знатно чвршћу контролу. Када је јануара 1801. убијен београдски везир Хаџи Мустафа-паша, управу над Београдским пашалуком преузеле су старешине одметнутих јаничара (дахије), које су потпуно поништиле полуаутономни статус православног становништва, потврђен са више фермана од лета 1793. до фебруара 1794. Након сазнања да су српски оборкнезови и друга угледна лица заједно са муслиманима лојалним султану планирали подизање устанка против њихове управе, дахије су се одлучиле на радикалне мере које би то спречиле: по њиховој замисли, кнезови и најугледнији свештеници били би убијени, а иста одмазда би се применила и на све мушке становнике Београдског пашалука који су у време последњег османско-хабзбуршког рата (1788-1791) имали десет и више година, док би остатак становништва био приморан да прихвати ислам. ${ }^{16}$ Тако замишљене екстремне мере нису имале готово никаквих изгледа на успех, посебно ако се има у виду опремљеност локалних Срба оружјем из времена док су служили у одредима Хаџи Мустафа-паше. Треба, такође, истаћи и то да централна власт, која је узурпаторе привидно признала док не реши проблем Османа Пазван-оглуа, са тим планом није имала везе, и да је он био супротан како шеријату тако и дотадашњој

\footnotetext{
${ }^{12}$ Пожар је избио у кући једног јеврејског трговца и брзо се ширио градом, јер је највећи број млађих и способних мушкараца који су могли спречити његово ширење био мобилисан, Исто, 47, 154.

${ }^{13}$ Исто, 48, 154.

${ }^{14}$ Васо Чубриловић, Босански фрајкори у аустриско-турском рату 1788-1791, Братство XXVII, Београд 1933, 4-6, 8, 18, 21-23, 30-31.

${ }^{15}$ С. Кемура - В. Ћоровић, нав. дело, док. 10, 426.

${ }^{16}$ Душан Пантелић, Београдски пашалук пред Први српски устанак 1794-1804, Београд 1949, 417-419; Славко Гавриловић, Ка српској револуиији, Историја српског народа IV/1, Београд 1986, 429.
} 
државној пракси. ${ }^{17}$ Преценивши своје снаге и потценивши могућност хришћана да се од тога одбране, дахије су почетком 1804. отпочеле сечу кнезова, у којој је страдало преко 70 најугледнијих Срба. Њихова последња жртва био је угледни архимандрит Хаџи Рувим Нешковић. Након тога, 2 (14) фебруара, подигнута је буна против дахија, односно Први српски устанак, који ће брзо прерасти првобитно локални значај. ${ }^{18}$ Предели Босанског пашалука, а самим тим и православних митрополија на његовом простору, биће непосредно изложени утицајима тих збивања.

Када је почео Први српски устанак, информације о тим збивањима стизале су Порти и преко Васељенске патријаршије. Београдски митрополит Леонтије Ламбровић је, преко територије Хабзбуршке монархије и Влашке, 3 (15) маја 1804. однео молбу коју су за султана послали устаници са Скупштине одржане у Остружници крај Београда. Султану је молба предата посредством васељенског патријарха. У тој молби су наведене све неправде које је српски народ у Београдском пашалуку претрпео од узурпатора власти. ${ }^{19}$ Убрзо се показало да је отпор дахија неодржив. Сем тога, устаници у почетку нису ни били у сукобу са државним властима, које су уклањање узурпатора доживљавале као користан чин, посебно важан за нов, коначан обрачун са Османом Пазван-оглуом у Видину. Зато нису третирани као побуњеници, већ су пре могли бити посматрани као лојални поданици, чији захтеви су се углавном сводили на враћање привилегија које су им одметнути јаничари бесправно поништили.

Када је реч о Босанском пашалуку, ситуација се битно разликовала у односу на простор Београдског пашалука. Док је у Београдском пашалуку османско турско друштво било једва присутно, ограничено на веће гарнизоне, вароши и касабе, а највише $10 \%$ становника било исламске вере, у Босанском пашалуку муслимански живаљ био је знатно бројнији, и чинио је значајну основу за попуну османске војске. Српски устанак у Босни зато није могао бити успешан, а ни православни хришћани нису имали намеру да масовно устану против власти. Они нису уживали привилегије које су имали Срби у Београдском пашалуку под управом Хаџи Мустафа-паше, и живели су под знатно тежим околностима. Број цркава и манастира био је мали, несразмеран броју верника, а цела провинција већ дуго је била почитлучена. Међутим, православни верници у Дабробосанској митрополији

\footnotetext{
17 Једини османски владар који је имао сличну идеју, да све хришћанско становништво Цариграда преведе у ислам а цркве претвори у џамије, тврдећи да се град није предао већ да је у целости био освојен, био је Селим I Јавуз (1512-1520). Од тога су га на молбу патријарха одговорили велики везир и други угледни муслимани, јер је намера била супротна шеријатском праву и привилегијама које је Мехмед Освајач дао првом патријарху по заузимању града, Генадију Схоларису. О томе шта се хришћанима спремало патријарха Теолепта I обавестио је управо велики везир Пири Мехмед-паша. Steven Runciman, The Great Church in Captivity, Cambridge 1968, 189-190. Тај пример из тада већ далеке прошлости који се односио на престоницу, свакако није био узор дахијама, који за њега можда нису ни знали.

${ }^{18}$ Д. Пантелић, нав. дело, 417-419.

${ }^{19}$ Радослав Перовић, Први српски устанак, акта и писма I, Београд 1977, док 30, 83; Велибор Берко Савић, Карађорђе, документа I, Горњи Милановац 1988, док. 14, 26; Н. Радосављевић, Шест портрета православних митрополита, 54.
} 
нису били изложени масовном терору попут оног у Београдском пашалуку након убиства Хаџи Мустафа-паше 1801. године. Мали део Босанског пашалука, на коме је устанак наишао на плодно тле, био је простор Јадра и Рађевине. Административно у Зворничком санџаку, а у погледу црквене организације део посебне, Зворничке митрополије, он се географски налазио на простору Србије. Запоседање тог простора од локалних устаничких снага практично је значило елиминисање османског мостобрана на десној обали Дрине. Мањи устанички покрети средином 1804. године у околини Сарајева, лоше организовани и без икаквих изгледа на успех, као и у области Дробњака у Херцеговини, више су били одраз локалних прилика, или подстакнути из Црне Горе. ${ }^{20}$

Османске власти су пажљиво пратиле да се ситуација из Београдског пашалука не прелије у суседне провинције. У почетку су постојали и контакти устаника са босанским везиром, Абу Бекир-пашом, али и са другим муслиманским првацима, попут Мехмед-капетана из Зворника и Хаџи-бега из Сребренице, којима безвлашће у непосредном суседству није одговарало. И сам Абу Бекир-паша срео се са Карађорђем извршавајући задатак да се Београдски пашалук очисти од јаничарских одметника, али то није успео до краја, јер је Београд остао у њиховим рукама. ${ }^{21}$ Српски устаници у то време нису сматрани непријатељским елементом, а сарадња са њима је постојала све до 1805 , односно до првог отвореног сукоба са регуларном османском војском на Иванковцу. Овај везир, коме је у обрачуну са дахијама приписивана недовољна одлучност, у Босанском пашалуку је очувао мир и заштитио хришћанско становништво од већих и систематских насиља. У томе је свакако имао и подршку највиших црквених великодостојника, међу њима и митрополита Калиника. Они, уосталом, другог избора нису ни имали.

Године 1804. живот на простору Дабробосанске митрополије текао је готово уобичајеним током. Митрополит Калиник I се тада жалио сарајевском кадији да не може да наплати све митрополитске приходе, као и на то да му локални чиновници праве одређене сметње. Његова жалба стигла је до Порте, која је одговорила са два фермана, којима се потврђују владичанска права, и наређује земаљским властима да митрополиту не само не сметају, већ да му помогну приликом вршења његових послова. ${ }^{22}$ Међутим, већ од следеће године ситуација се постепено усложњава, на шта пресудно утичу догађаји у Београдском пашалуку, у коме првобитна буна против дахија прераста у прву националну револуцију на Балкану, чији је циљ био ослобођење од османске власти. Да би заштитиле мирне поданике, централне власти су морале да путем султановог фермана нареде тадашњем босанском везиру Мустафа-паши и сарајевском кадији да спрече насиље над хришћанима и казне све који прекрше ту заповест. ${ }^{23}$ Уочи очекиваних ратних припрема босанске војске, у интересу власти било је да она има мирну позадину.

\footnotetext{
20 М. Екмечић, Место Босне и Хериеговине у Српској револуцији 1804-1815, Српска револуција 1804-1815. и Босна и Херцеговина, Бања Лука 2004, 48.

21 Ангелика Кос, Босанско Подриње у устаничким плановима и операчијама, Српска револуција 1804-1815. и Босна и Херцеговина, Бања Лука 2004, 552.

${ }^{22}$ С. Кемура - В. Ћоровић, нав. дело, док. 14, стр. 427.

${ }^{23}$ Исто, док. 15, стр. 427-430.
} 
Митрополит Калиник је у Цариграду у патријаршијским круговима уживао велики углед, јер је крајем 1807. или почетком 1808. био изабран за синодског митрополита, али је за то време задржао и право управе над својом епархијом. ${ }^{24} \mathrm{OH}$ је био први дабробосански митрополит који је постао члан тог тела, што је била велика част. Његов избор је, такође, потврђивао висок ранг Дабробосанске митрополије у патријаршијској структури. Након његовог одласка управу над Митрополијом практично је преузео његов викарни епископ Венедикт Краљевић. Он је имао добро образовање, стечено по грчким манастирима и школама, а једно време био је и учитељ деце влашког кнеза. Потом се вратио у Османско царство и отишао у Свету Земљу. Краће време боравио је у неком од синајских манастира. Године 1805. добио је дозволу да сакупља милостињу за синајске манастире у Далмацији. По повратку из Далмације задржао се у Босни, где га је митрополит Калиник, заједно са рашко-призренским митрополитом Јоаникијем и херцеговачким митрополитом Јеремијом, рукоположио за свог викарног епископа, титуларног митрополита кратовског, с тим да му у време одсуства из епархије исплаћује одређену суму новца. Ту Калиникову одлуку морале су да потврде Васељенска патријаршија и османске власти, јер без њихове сагласности не би била реализована. $^{25}$

У време Калиникове управе, као и за време самосталне управе Венедикта Краљевића, положај православних поданика у Босанском пашалуку био је веома сложен. Операције босанске војске против српских устаника пратили су порази и губици у људству, а део православних је приликом продора устаничке војске у Босну приступио њој, што је довело и до миграције ка Србији када је почело њено повлачење. Умножила су се и насиља неодговорних локалних носилаца власти или војника који су се у нереду враћали са ратишта, посебно после битака на Мишару 1806. и код Лознице 1807. Од православних хришћана је, као што се у таквим околностима дешавало, одузимано оружје, а за мирно понашање раје јамчили су њени прваци. На основу чињенице да је тражено јемство за лојалност митрополита Венедикта Краљевића, може се закључити да је та мера примењена и 1807. године. Управо то је био његов велики проблем. Док је митрополит Калиник, који је тада вероватно већ био у Цариграду, настојао да олакша положај својих верника у време када је босанска османска војска на ратиштима трпела поразе, викарни епископ Краљевић имао је друге, у великој мери неоствариве замисли о подизању устанка у Босни. У српској историографији преовладало је мишљење да је због сумњи да је подложан симонији био непопуларан у Сарајеву, па за њега нико није хтео да гарантује. Поред његове авантуристичке природе, то је био један од основних

\footnotetext{
${ }^{24}$ Митрополит Калиник је, као синодски архијереј, потписан у Синодалном акту о самосталности патријаршијске егзархије Мецова у Епиру, Драгутин Анастасијевић, Кроз једну збирку новијих аката Цариградске патријаршије, Богословље VIII, свезак 2, Београд 1933, 111. Митрополит Калиник постао је сигурно синодски митрополит пре почетка априла 1808, јер је у то време већ био у Цариграду у том својству, одакле се писмима обраћао, између осталих, и Краљевићевом писару, Архив САНУ у Сремским Карловцима, Фонд Б , Сремски карловци, бр. 1- V/1808. (АСАНУК, Фонд Б).

${ }^{25}$ Н. Радосављевић, Краљевић, Венедикт, Српски биографски речник V, Нови Сад 2011, 326-327.
} 
разлога због чега се одлучио да емигрира у Хабзбуршку монархију, земљу која је покушавала да привидно очува неутралну позицију.

Краљевић је, обећавши да ће прикупити одређену суму новца за свој откуп, био пуштен из травничког затвора, а у Хабзбуршку монархију прешао је 26. августа 1807. Његово објашњење о разлозима преласка, дато хабзбуршким пограничним властима, није се састојало од молбе за лично спасавање. Он је изнео намеру да тражи заштиту суседне силе и помоћ у дизању буне у Босни. Владимир Ћоровић сматра да је, с обзиром на његове личне контакте, заиста радио на подизању буне, што се касније и показало тачним у случају Јована Јанчића. ${ }^{26}$ И цар Франц I већ је имао сазнања о тешкој ситуацији у Босанском пашалуку, али су му односи са Француском, која је преузела контролу над хабзбуршким поседима у Далмацији, онемогућавали да ради било шта на могућој акцији у пограничним османским областима. ${ }^{27}$

Карловачки митрополит Стефан Стратимировић примио је вести о Краљевићевом преласку границе почетком септембра 1807. Он му је, као и 1806. ужичко-ваљевском митрополиту Антиму, за боравиште одредио манастир Бешеново. Стратимировић, међутим, није према њима имао исти приступ: док је према Антиму Зепосу показивао велику наклоност и позивао га код себе у госте у Сремске Карловце, у случају Венедикта Краљевића био је јасан, одредивши поменути манастир као једино место његовог привременог боравка. ${ }^{28}$

После само неколико месеци Краљевић је прешао у Србију, где се придружио београдском митрополиту Леонтију, да би се већ у мају 1808. са руским пасошем појавио у Далмацији која је била под француском влашћу, и ставио се на располагање генералу Мармону. ${ }^{29}$ Патријаршија је будно пратила његово кретање, о чему је сигурно била извештена и од османских власти Босанског пашалука. И док је викарни епископ емигрирао, посебну пажњу шта се дешава у његовој епархији показивао је управо сарајевски митрополит Калиник I. O стању у епархији био је информисан преко Краљевићевог писара, који није следио његов пут, већ је остао у Хабзбуршкој монархији. Његовим посредством Патријаршија је одржавала везу и са ужичко-ваљевским митрополитом Антимом Зепосом, који се у то време у истој држави лечио од тешког облика скорбута. ${ }^{30}$

У случају Венедикта Краљевића, један детаљ привлачи посебну пажњу: он је пуштен из османског затвора да би за себе прикупио суму која властима гарантује његову лојалност. Османске власти знале су да он тај новац нема, а дуг који би начинио прикупљајући га везао би га за тај простор, јер би и повериоци пратили

\footnotetext{
${ }^{26}$ В. Ћоровић, Историја Срба ІІІ, Београд 1989, 46-47.

${ }^{27}$ Исто, 47.

${ }^{28}$ Митрополит Антим Зепос је по сопственој жељи са пратњом октобра 1806. смештен у Бешенову, након што су хабзбуршке војне власти тражиле да све избеглице из Србије буду удаљене од границе. До тада, он се налазио у Сремској Митровици, Р. Перовић, О шабачком владици Антиму, Београд 1941, 9-10.

${ }^{29}$ Никодим еп. Милаш, Православна Далмација, Нови Сад 1901, 478-479. Руски пасош за одлазак из Србије и пут до Далмације Краљевићу је дао руски представник у устаничкој држави, Родофиникин, Ђ. Слијепчевић, нав. дело, 462.

${ }^{30}$ АСАНУК, Фонд Б, бр. 1-I/1808.
} 
његово кретање и спречавали га да напусти митрополију. Међутим, Краљевић новац није ни покушао да прикупи, већ је напустио земљу.

Чињеница да се налазио у затвору у време устаничких успеха указује на то да се слично могло десити и са другим архијерејима из Босанског пашалука. Власти су примењивале обичај да се у време кризних ситуација архијереји, као представници православног хришћанског милета, затварају и приморавају да шаљу прокламације верницима да остану мирни и одани султану да би их затим, пошто би их оглобиле, пуштале на слободу. Такву судбину можда би доживео и митрополит Калиник да се у то време налазио у епархији. Тај обичај примењиван је и касније. У устаничком периоду, међутим, ова мера била је можда примењена само на Краљевића, јер су херцеговачки, зворнички и рашко-призренски митрополити углавном били на слободи. Херцеговачки митрополит Јеремија је, на пример, знајући да је његова епархија под чврстом контролом османских власти, позивао вернике на мир, док је зворнички митрополит у једном тренутку чак био ангажован и у покушајима османских власти да мирно, преговорима са устаницима, реше српско питање. ${ }^{31}$ У том послу сигурно је тражено и мишљење дабробосанског митрополита Калиника.

До територије коју су контролисали Французи Венедикт Краљевић могао је доћи само преко Хабзбуршке монархије, јер би у противном био ухапшен да је покушао да то учини преко османске територије. Како је митрополит Калиник I остао у Цариграду као синодски архијереј, јер се у истом својству јавља и као потписник акта о спајању Нишке и Нишавске (Пиротске) митрополије у једну епархију под нишким митрополитом Мелетијем 1815. године, могуће је да је све до 25. октобра 1816, када је султановим бератом потврђен нови дабробосански митрополит Венијамин, није враћао у њу. ${ }^{32}$ Међутим, то не значи да је митрополија остала без архијерејског старања. У таквим ситуацијама Патријаршија је водила рачуна да се то питање што пре реши. Она је имала чврсту и добро организовану структуру, и до занемаривања и запуштања неке од епархија није могло да дође. Одласком Краљевића, који је својим деловањем изазвао само подозрење османских власти, решено је и питање новог викарног епископа: већ 1809. као митрополит кратовски помиње се Јосиф, сестрић Калиника І. Шест година касније, након смрти херцеговачког митрополита Јеремије 29. јула (10. августа) 1815 , Јосиф је отишао у Цариград, и тамо био постављен на његово место. ${ }^{33}$ Међутим, све до доласка новог митрополита Венијамина, он је наставио да управља и Дабробосанском

\footnotetext{
${ }^{31}$ Н. Радосављевић, Херцеггвачки митрополити 1766-1878, Историјски часопис 57, Београд 2008, 180; У једном од писама насталом на османскотурском језику од 18. шевала 1227 (25. октобра 1812) у Цариграду, коме због механичких оштећења није могуће утврдити пошиљаоца и примаоца, наводи се да је софијски назир обавештен да је васељенски патријарх наредио зворничком митрополиту Гаврилу да по српском питању поново да своје савете, Народна библиотека Св. Св. Кирил и Методиј, Ориентална архивна колекция, София, бр. 17/85 (НБКМ, ОАК).

${ }^{32}$ Митрополит Венијамин претходно је био управитељ патријаршијског двора у Цариграду. С. Кемура В. Ћоровић, нав. дело, док 14, 433; Ђ. Слијепчевић, нав. дело, 462.

${ }_{33}$ Јоаникије Памучина, Лжтопись преавославне иркве далматинске и херцеговачке. Почетак долазка грчки владика у Хериеговину, Србско-далматинскій магазинъ за л кто 1848, Задар 1848, 173-174.
} 
митрополијом. Митрополит Јосиф се из Цариграда сигурно вратио пре 1 (13) марта 1816 , када је издао једну синђелију свештенику Ђорђу у власеничком кадилуку, којом је одредио које приходе може да узима од верника. На том документу стајао је његов нови печат, на коме је, у централном делу на османскотурском а по ободу на грчком, урезан текст који гласи: Јосиф, митрополит хериеговачки. Саму повељу митрополит је потписао речима Ерцеговачки Јосиф и молитвеник ваш, али су у Дабробосанској митрополији свакако знали да се ради о њиховом архијереју, који је још увек вршио своју дужност до доласка новоизабраног митрополита. ${ }^{34}$ Тако је решено једно важно питање из историје Дабробосанске митрополије, и потврђена чињеница да је након Краљевићевог напуштања епархије 1807. брзо успостављена канонска структура и редован поредак у њој.

У ванредним околностима у којима се за време ратног периода Српске револуције налазио Босански пашалук, архијерејска брига у Дабробосанској митрополији била је неопходна јер су епископи, као представници целокупног хришћанског православног милета, пред земаљским властима били одговорни за понашање својих верника. Међутим, под утицајем српских устаничких акција, део њих је узео активно учешће у рату прикључивши се српској војсци. Исто тако, у Босни су избијале спорадичне побуне које су османске власти лако гушиле, али су последице како за учеснике тако и за хришћане у областима где су избијале биле тешке. Године 1805 , у источној Херцеговини се, захваљујући деловању игумана пет манастира (Завала, Дужи, Добриловина, Житомислић, Пива) и локалних народних старешина, формирала војска која је, по хабзбуршким проценама, имала до 19.000 припадника. Устанак који је избио у Дробњаку временом се угасио, јер комуникација са Карађорђем није била правовремена. Касније, црногорски владика Петар I Петровић Његош је у договору са Русијом дејство својих одреда усмеравао против француске војске у Дубровнику и Боки. Већ раније, хајдучке чете су се у већем броју појавиле у прстену српских села око Сарајева. ${ }^{35}$

Највећи устанички покрет у Босни била је буна коју је 1809. организовао Јован Јанчић, пушкар из Босанске Градишке. Иако су локална организација и окупљање устаника били његово дело, значајан утицај на те догађаје извршио је пребегли викарни епископ Венедикт Краљевић. Јанчић је с њим био у преписци коју су хабзбуршке власти пратиле. Краљевић га је чак позивао и на договор о томе, а цела идеја о подизању устанка у Босни прослеђена је и руском двору, одакле није било никакве реакције. ${ }^{36}$ Додатне чињенице о Јанчићевој буни 1809. дао је Ђорђе Микић. Он је указао да је комуникација Јанчића и Краљевића трајала готово све време од када је епископ прешао у Хабзбуршку монархију, да га је Јанчић посетио док је боравио у манастиру Бешенову и предлагао му да се за помоћ прво обрати цару Францу I, као и то да је у циљу подизања устанка одржавана веза и са низом

\footnotetext{
${ }^{34}$ Синђелија митрополита Јосифа јереју Борђу од 1. (13) марта 1816 (приредио С. Б.), Дабробосански источник за 1887, Сарајево 1887, бр. 1, св. 6, 93.

${ }^{35}$ Процена о 19.000 устаника свакако је претерана, М. Екмечић, Место Босне и Херцеговине у Српској револуцииј 1804-1815, 47-48, 58.

${ }^{36}$ Исто, 63.
} 
православних свештених лица, због чијег држања ће касније страдати и многи свештеници који са устанком нису имали никакве везе. ${ }^{37}$

Устаници су били окупљени 23. септембра 1809, али је Јанчић откривен, ухапшен и убрзо погубљен. Налазећи се између река Уне и Босне, далеко од српске војске, слабо наоружани и лоше вођени, они нису успели да угрозе османску власт. Одмазда је била сурова, о чему је и темишварски епископ Јосиф Путник обавестио Стратимировића. Исто тако, страни конзули су у Травнику могли лично да се увере у то како су извршаване смртне казне. Православно свештенство је посебно било на удару, као и цркве и манастири. ${ }^{38}$ Ови догађаји показали су да је викарни епископ Краљевић имао одређен утицај у неким деловима Босне. Међутим, његове процене о могућем успеху устаника, засноване на неутемељеним претпоставкама о помоћи страних сила и ослонцем само на српску војску, нису биле добре. Све време османске власти су пратиле његову и Јанчићеву делатност, и спремно дочекале избијање буне. Због тога је устанак брзо био угушен. Након објављене амнестије у новембру 1809, више није било озбиљног покушаја да се подигне устанак докраја ратног периода Српске револуције. ${ }^{39}$ Смиривању ситуације, која је била трагична како по учеснике устанка тако и по обичне вернике и свештенство, својим деловањем несумњиво је допринео и викарни епископ митрополита Калиника I, титуларни митрополит кратовски Јосиф.

Улога архијереја Васељенске патријаршије у време устаничких покрета у српским земљама често је била предмет спорења. У време постојања Пећке патријаршије, посебно током Великог бечког рата 1683-1699, и хабзбуршкоосманског рата 1737-1739, део епископа и два патријарха ставила су се на страну хришћанских сила, отказавши послушност османској власти. Њихова акција довела је до две велике сеобе ка простору који је остао под влашћу Хабзбуршке монархије, а предели где су се водиле ратне операције били су готово опустели. У Првом и у Другом српском устанку део свештеника учествовао је у народним скупштинама и војним акцијама, иако су и од карловачког митрополита Стратимировића били саветовани да не узимају оружје у руке, већ да служе у црквама и на народ утичу речју и саветом. ${ }^{40}$

Чињеница је да архијереји Васељенске патријаршије који су били у епархијама насељеним верницима претежно српског и другог словенског порекла, уз изузетке попут београдског митрополита Леонтија Ламбровића или Венедикта Краљевића, нису учествовали у плановима за подизање устанака. У српској историографији присутно је и мишљење да то нису чинили зато што су били углавном Грци или грчки васпитаници, блиски османским властима. Међутим,

\footnotetext{
${ }^{37}$ Ђорђе Микић, Буна Јована Јанчића, Српска револуција 1804-1815. и Босна и Херцеговина, Бања Лука 2004, 220-224.

${ }^{38}$ Исто, 231-234.

${ }^{39}$ Исто, 235.

${ }^{40}$ Није добро да свјаштенство и калуђери оружја носе, у бој иду, иеркве и молапстивија оставе и приме се званија које није ьиово...Они сваштеници који су међу војводама сада да не забораве да су свјаштеници, и само поученијем, словом, саветом и бодренијем, а не оружијем, сабљом и пушком да началствују..., Н. Радосављевић, Православна ирква у Београдском пашалуку 1766-1831, 340-341.
} 
подизање устанака и учешће у њима није била њихова мисија. Они су знали да ће њихова делатност на европској периферији Османског царства у таквој ситуацији имати последица и по православне хришћане у целој држави, па и на саму Патријаршију која је била веома рањива, јер јој је центар био у престоници, и о томе су водили рачуна. Зато су у кризним временима, какво је без сумње било ратно доба Српске револуције, пре свега деловали у смеру заштите својих верника. То су чинили дабробосански митрополит Калиник и његов викарни епископ Јосиф, али и херцеговачки, зворнички и рашко-призренски митрополити, ограничивши се на духовну мисију и представљање народа пред властима. На простору Босанског пашалука у чијим оквирима су деловали, није било услова за успех устанка у том тренутку, и они су то добро знали.

Верници и свештеници Дабробосанске митрополије су, након пропасти Првог српског устанка, у значајној мери помогли да се спасу бројне богослужбене књиге, антиминси и друге светиње, које су османски војници опљачкали по црквама на ратиштима где су били, и донели у свој завичај. Та пракса била им је својствена и у ранијим ратовима. Цркве и манастири пљачкани су и паљени, а посебно су страдале иконе и живописи. Међутим, богослужбене књиге су узимане и касније продаване, што значи да су војници који су живели у окружењу комшија православне вере знали колика је њихова вредност, како новчана тако и она која се односи на духовну димензију. Откупљујући их из османских руку, локални православни хришћани исказивали су своју побожност дарујући их својим парохијским црквама или манастирима, или их враћајући власницима. Тако су књиге из манастира Раче, чији је архимандрит био Хаџи Мелентије Стефановић, устанички војвода Соколске нахије, на крају завршиле у рукама сарајевских хришћана, а слично је било и са књигама из манастира Грабовца и Раванице, из села у Ваљевској нахији и других места. ${ }^{41}$ Селективно пљачкање цркава и манастира, и пажљив одабир књига и других предмета који су могли бити продати православним хришћанима, потврђују да је таква врста одмазде била планска и систематски спровођена.

И током Другог српског устанка 1815, у борбама против устаника учествовала је османска војска из Босанског пашалука, али је он кратко трајао и на простору који је обухватала Дабробосанска митрополија није произвео значајније дејство. У ратним операцијама од 1804, посебно у источној Босни, страдао је један број цркава, које су постепено обнављане након окончања борби. Након Другог српског устанка уследила је обнова старих храмова, за које се са сигурношћу може тврдити да су оштећени и запустели у устаничком времену. Тај процес трајао је дуго, јер су дозволе за радове скупо коштале и споро су издаване.

Нови митрополит Венијамин дошао је на чело Дабробосанске митрополије у мирно време, али двадесетих и тридесетих година 19. века положај православног

\footnotetext{
${ }^{41}$ Ђорђе мит. Николајевић, Старе књиге, Дабробосански источник, лист за црквено-просвјетне потребе српско-православног свештенства у Босни и Херцеговини 1, Сарајево 1887, св. 1, 26; св. 3, 43; св. 4, 58; Исти, Старе књиге, Дабробосански источник 2, Сарајево 1888, св. 1, 12-13; св. 2, 267; Исти, Старе књиге, Дабробосански источник 3, Сарајево 1889, св. 4, 46.
} 
становништва у Босанском и у Београдском пашалуку временом се све више разликује. Док у Београдском пашалуку кнез Милош Обреновић постепено изграђује српску аутономију, што ће довести до стварања аутономне Кнежевине Србије 1830. и аутономне Православне цркве у њој 1831, православни верници у Босанском пашалуку, а посебно у Дабробосанској митрополији, постаће невољни сведоци и учесници догађаја који ће се негативно одразити и на њихов положај. Та тешка времена почеће са Грчким устанком 1821, а продужиће се због побуна босанског беговата против реформи које је покушавала да спроведе централна власт.

На крају, може се закључити да је у време трајања ратног периода Српске револуције на простору Дабробосанске митрополије углавном очуван мир, изузев мањих устаничких покрета који нису имали изгледа на успех, и повремених прелазака устаничке војске преко Дрине. Све то време сарајевски митрополит био је Калиник I (1802-1816), али је од краја 1807. боравио у Цариграду као синодски архијереј, док су га у епархији замењивали викарни епископи, прво Венедикт Краљевић (1807-1808), а затим и његов сестрић Јосиф (1809-1816). Изузимајући идеје Венедикта Краљевића о подизању устанка, сви други архијереји у Босанском пашалуку, на челу са митрополитом Калиником I, одговорно су вршили своју дужност и код локалних власти покушавали да заштите своје вернике, схватајући да не постоје реални изгледи за успех таквог подухвата у Босанском пашалуку. Они су се искључиво држали своје духовне мисије, и понашали су се у границама које им је одредило османско законодавство, као представници православног милета у својим епархијама пред државним властима. На тај начин, верници су поштеђени већих страдања, а посебно одмазде која је уследила по слому српске устаничке државе.

\section{Извори и литература:}

Извори:

Архив САНУ у Сремским Карловичима, Фонд Б, Сремски Карловци, бр. 1-I/1808, бр. 1- V/1808. (АСАНУК, Фонд Б),

Народна библиотека Св. Св. Кирил и Методиј София, Ориентална архивна колекиия бр. 17/85. (НБКМ; ОАК)

Анастасијевић, Драгутин, Кроз једну збирку новијих аката Цариградске патријаршије, Богословље VIII, свезак 2, Београд 1933, 109-123.

Јастребов, Иван. С., Податщи за историју Српске иркве, Београд 1879.

Кемура, еф. Сејфудин- Ћоровић Владимир, Прилози за хисторију Православне иркве у Босни и Хериеговини у XVIII и XIX стољећу, Гласник Земаљског музеја у Босни и Херцеговини XXIV, Сарајево 1912, 413-441.

Николајевић, мит.Ђорђе, Старе књиге, Дабробосански источник, лист за црквено-просвјетне потребе српско-православног свешзенства у Босни и Херцеговини 1, Сарајево 1887, св. 1,26 ; св. 3,43 ; св. 4,58 .

Николајевић, мит.Ђорђе, Старе књиге, Дабробосански источник 2, Сарајево 1888, св. 1, $12-$ 13; св. 2, 267. 
Николајевић, мит.Ђорђе, Старе књиге, Дабробосански источник 3, Сарајево 1889, св. 4, 46.

Перовић, Радослав, Први српски устанак, акта и писма I, Београд 1977.

Радосављевић, Недељко, Грађа за историју Сарајевске (Дабробосанске) митрополије, Београд 2007.

Синђелија митрополита Јосифа јереју Ђорђу од 1. (13) марта 1816 (приредио С. Б)., Дабробосански источник за 1887, Сарајево 1887, бр. 1, св. 6, 93

Савић, Велибор Берко, Карађорђе, документа I, Горњи Милановац 1988.

Стојановић, Љубомир, Стари српски записи и натписи I - VI, Београд - Сремски Карловци 1902-1926.

\section{Литература:}

Вуковић, еп.Сава, Српски јерарси од деветог до даведесетог века, Београд-Подгорица Крагујевац 1995.

Гавриловић, Славко, Ка српској револуцији, Историја српског народа IV/1, Београд 1986, 351-431.

Đurđev, Branislav, Uloga crkve u starijoj istoriji srpskog naroda, Sarajevo 1964.

Екмечић, Милорад, Место Босне и Херцеговине у Српској револуиији 1804-1815, Српска револуција 1804-1815. године и Босна и Херцеговина, Бања Лука 2004, 37-71.

Кос, Ангелика, Босанско Подриње у устаничким плановима и операиијама, Српска револуција 1804-1815. и Босна и Херцеговина, Бања Лука 2004, 551-563.

Madžar, Božo, Pokret Srba u Bosni i Hercegovini za vjersko-prosvjetnu samoupravu, Sarajevo 1982.

Милаш, еп. Никодим, Православна Далмаиија, Београд 1989.

Микић, Ђорђе, Буна Јована Јанчића, Српска револуција 1804-1815. и Босна и Херцеговина, 219-238.

Нилевић, Борис, Српска православна ирква у Босни и Херцеговини до обнове Пећке nатријаршије, Сарајево 1998.

Памучина, Јоаникије, Лћтописъ преавославне иркве далматинске и хериеговачке. Почетак долазка грчки владика у Хериеговину, Србско-далматинскій магазинъ за льто 1848, Задар 1848,169-181.

Пантелић, Душан, Београдски пашалук пред Први српски устанак 1794-1804, Београд 1949.

Перовић, Радослав, О шабачком владиии Антиму, Београд 1941,

Радосављевић, Недељко, Православна ирква у Београдском памалуку 1766-1831, управа Васељенске патријариије, Београд 2007.

Радосављевић, Недељко, Шест портрета православних митрополита 1766-1891, Београд 2009.

Радосављевић, Недељко, Краљевић Венедикт, Српски биографски речник V, Нови Сад 2011, 326-327.

Runciman, Steven, The Great Church in Captivity, Cambridge 1968.

Слијепчевић, Ђоко, Историја Српске православне цркве II, Београд 1991.

Скарић, Владислав, Српски православни народ и ирква у Сарајеву у 17. и 18. вијеку, Изабрана дјела II, Сарајево 1985.

Чубриловић, Васо, Босански фрајкори у аустриско-турском рату 1788-1791, Братство XXVII (сепарат), Београд 1933, 3-31.

Ћоровић, Владимир, Историја Срба III, Београд 1989. 


\title{
DABAR-BOSNIA (SARAJEVO) METROPOLIS IN THE WAR PERIOD OF SERBIAN REVOLUTION (1804-1815)
}

\begin{abstract}
Summary
Dabar-Bosnia (Sarajevo) Metropolitan was one of the four dioceses of the Bosnian Sanjak, and the largest and most populated diocese in general, settled by the Orthodox Serbs. During the First and the Second Serbian Uprising, it was located on the very border of the uprising state, which was directly exposed to influences arising from the war. Metropolitan Kalinik I was the head of it all the time. After he was elected Synod Metropolitan in 1807, the Metropolitan was run by the vicar bishops, first by Venedikt Kraljević, and then by Josif. The war spreaded to the area of Bosanski pashaluk, and a number of Serbs took part in the insurrectionist movements. However, there was no broader uprising due to a high concentration of the Ottoman army. Dabar-Bosnia Metropolitan Kalinik and Vicar Bishop Josif greatly contributed to calming the situation, and protecting the believers from violence, by intervening with the Ottoman authorities.
\end{abstract}

Keywords: The Ecumenical Patriarchate, the Ottoman Empire, Sarajevo, Metropolitan, the Serbian revolution, church, metropolitans, the believers. 